\title{
The Balyan Family and the Linguistic culture of a Parisian Education
}

\section{Alyson Wharton}

Karapet Balyan (1800-1866) and his sons, Nigoğos (1826-1858), Serkis (1831-1899) and Agop (1837-1875), dominated the construction of imperial works under Abdülmecid (r. 1831-1861) and Abdülaziz (r. 1861-1876). They built Dolmabahçe Palace (1856), Ortaköy Mosque (1854-5), Ihlamur Kiosk (1853), schools such as Cemaran Mektebi (1838) and government buildings such as the Naval Ministry (1865-9). Nigoğos, Serkis and Agop were among the earliest Ottoman architects educated in Paris. Rahip Yeprem Boğosyan, ${ }^{1}$ Pars Tuğlacı ${ }^{2}$ and Kevork Pamukciyan ${ }^{3}$ have used Armenian periodicals to document their stays. However, Aygül Ağır has drawn attention to the fact that these were not official sources and has questioned the nature of the Balyans' enrolment. ${ }^{4}$

This article clarifies Nigoğos' and Serkis' educational status, using fresh archival documentation. Reading a Parisian education as interactional expertise, it offers a reinterpretation of the Balyans' architecture as an adaptation of the linguistic culture of Paris to Ottoman building traditions and imperatives for displaying imperial power. ${ }^{5}$ Charting their assimilation of approaches to architectural communication from the institutions that they attended (Collège Sainte-Barbe, École Centrale and the Beaux-Arts), the article shows how these were adapted to the Ottoman context. It argues that the Balyans were not agents of change responsible for the desertion of Ottoman forms nor were they 'men of practice' who were not engaged in the debates of their time. Instead, they were fully immersed in the methods of communicating, or linguistic culture, of these institutions, including their intellectual underpinnings. In the end, however, they never graduated and the aspects of their education that they implemented were done as a form of communication on the surface of their buildings. Thus their expertise can be considered a mixture of formal and informal, or interactional expertise, rather than as a straightforward transition to professionalization.

Texts produced in the late Ottoman period narrated the development of Ottoman architecture in formalist terms. Celal Esad Arseven portrayed the eighteenth and early nineteenth centuries as the 'Baroque Age' and the 'Empire Age', developing into a European mode (Avrupa karl) under Abdülaziz, which Arseven heralded as 'Intibah Devri' (Age of Awakening). During this period, a mixed and adulterated style appeared (karlşı ve mahlut bir uslup), characterized by Pertevniyal Valide Sultan Mosque in Aksaray (1872) and the Çırağan Palace (1871), both of which were Balyan works. Arseven described their role in general terms, stating that 'Armenian architects educated in Europe continued to bring buildings in a baroque and renaissance style into existence'. ${ }^{6}$ Arseven viewed a text produced for the 1873 Vienna Exposition, Usul-u Mimari-i Osmani (the Rules of Ottoman Architecture), as the beginning of a scientific approach. ${ }^{7}$

As Sibel Bozdoğan has shown, the views of Arseven dominated the republican perspective of Ottoman architecture. ${ }^{8}$ There was a desire to present Ottoman architecture as distinct from orientalist conflations of Arab, Indian, Iranian and Turkish styles. ${ }^{9}$

The question of why the Usul and Arseven praised the Valide Mosque and Çırağan Palace as an 'Awakening' or an 'Ottoman Renaissance', ${ }^{12}$ when these works blended Islamic and nonIslamic traditions, has never been explained satisfactorily. Ahmet Ersoy ascribed it to the Usul's role as 'an officially prescribed agenda of Ottoman modernization'. ${ }^{13}$ Ersoy, at the 
time, did not see any connection between the circle responsible for the Usul and the Balyans.. ${ }^{14}$

Aside from Boğosyan, Pamukciyan and Tuğlac1's biographical accounts, it was only a recent exhibition catalogue that began to observe the Balyans as creative actors. One contribution by Ersoy translated a proposal that Serkis wrote for a school of arts and industry, focussing on his technical education as a reflection of the professionalization of the Ottoman builder (kalfa). ${ }^{15}$

This article argues that, through their exposure to a Parisian education, Nigoğos and Serkis gained linguistic socialization and took on aspects of the prevailing linguistic culture. Harold F. Schiffman has given a definition for this as:

... the set of behaviours, assumptions, cultural forms, prejudices, folk belief systems, attitudes, stereotypes, ways of thinking about language, and religiohistorical circumstances associated with a particular language. ${ }^{16}$

In other words, linguistic culture is an aspect of acculturation. It is a way of communicating or a 'degree of commonality in the understandings of how language is to be used to get certain things done'. ${ }^{17}$

As the examination here will indicate, the Balyans assimilated methods of (architectural) communication taught in Paris. These were accommodated within works ${ }^{18}$ which retained an Ottoman framework, floor plans and messages (relating to the power of the sultan and his territorial sovereignty). Therefore, the Balyans' underlying material form of life and contributory experiences shaped the new works. This picture contrasts with views on Ottoman development that stress 'translations' or 'purchase' and claim an indigenous tradition in science and industry failed to develop. ${ }^{19}$

Yet, the Balyan family did not graduate from the institutions that they attended. Due to this ambiguity in their status and the adaptive nature of their works, one reads their education as a prototypical form of interactional expertise. This is a realm of knowledge that resides between the formal and informal, or 'the ability to converse expertly about a practical skill or expertise, but without being able to practice it, learned through linguistic socialization among the practitioners'. ${ }^{20}$

There is typically an opposition between these two types of knowledge (formal and informal). ${ }^{21}$ In the history of art, this is seen in the difference between medieval practicebased master builders and architects of the Renaissance who theorized their works. In the Ottoman Empire, there is the related development from kalfa to professionalization. However, such a division underestimates the blend of master builder and architect that figures like the Balyans represented.

Interactional expertise includes the subject becoming 'immersed, not in the entire form of life of some domain but only in the language-world of those who were immersed in the form of life proper'. ${ }^{23}$ Through linguistic socialization, tacit skills are gained, but a full practical training is not. The engagement of the Balyans in the language of Parisian practitioners is seen in several aspects explored here: first, Nigoğos' intellectual transformation through exposure to the Sainte-Barbe and the language of romanticism, second, Serkis' adoption of 
the pragmatic approach of the Centrale and third, the revivalist ornament he used, following ideas propounded at the Beaux-Arts.

The Balyans' Parisian education demonstrates interactional expertise over and above other forms of expertise, including 'contributory' or 'full'. ${ }^{24}$ This is because they became linguistically socialized through mixing with students in ateliers, participating in project work, rituals and ceremonies, which encouraged fraternity amongst alumni. On a formal level, the pedagogy encouraged a particular mode of architectural communication.. Nigoğos and Serkis connected with this world through their imagination and empathy: they participated in the intellectual movements prevalent at these institutions, most notably that of romanticism, and they used this to rethink their approach to Ottoman architecture. ${ }^{25}$ They assimilated what was taught and adapted it. However, they never became full practitioners: new expertise was implemented in conjunction with traditional plans and messages. Thus Ottoman identity, or 'material form of life and distinct contributory experiences' remained strong. ${ }^{26}$

\section{The Language of the Sainte-Barbe: Nigoğos’ Romantic Transformation}

Armenian sources state that Nigoğos, Serkis and Agop all attended the Collège SainteBarbe. ${ }^{27}$ Student registers of the École Préparatoire show that a 'Ballian' was present in the 1848-49 schoolyear. ${ }^{28}$ This must have been Serkis, who travelled to Paris in 1848 (Nigoğos returned to Constantinople in 1846). ${ }^{29}$

The Sainte-Barbe was an important institution for elite education in the nineteenth century. Henri (1801-1875) and Théodore (1799-185) Labrouste met Léon Vaudoyer (1803-1872) at Sainte-Barbe. ${ }^{30}$ From the 1840 s onwards, the school held a pivotal role in the education of Ottomans, including Armenians, who became diplomats, such as Artin Dadian (1830-1901), ${ }^{31}$ and intellectuals, such as Istepan Oskanyan (1825-1901). ${ }^{32}$

In the year that Serkis Balyan attended, illustrious classmates included, in 1848-49 an unspecified Labrouste, and in 1850-51, Gustave Eiffel (1832-1923). It is possible that Eiffel and Balyan would have known each other as they both progressed to the Centrale and Izmir Konak Pier has been connected to Eiffel. ${ }^{34}$

Such networks could become useful for professional operations. Armenian architect 'Jacob Mélick' (born 1817), who attended Sainte-Barbe and the Beaux-Arts, when employed to build the residence of banker Migırdiç Cezayirliyan (1805-1861), brought with him Pierre Victor Galland (1822-1892) and Charles Séchan (1803-1874). ${ }^{35}$ Léon Parvillée (1830-1885), a French architect, decorator and ceramicist, was another member of the team. Several of these individuals later worked on the Dolmabahçe Palace. ${ }^{36}$

The networks of Sainte-Barbe's drawing teachers also show the potential for making connections. ${ }^{37}$ Jules Ernest Panis (1827-95) exhibited at the salons of 1850 and 1874 had students including Jean-Baptiste-Camille Corot (1796-1875). Tournachon Nadar (18201910) was a friend and (Ingrès' student) Henri Lehmann (1814-82) was Panis' teacher. A dossier concerning Léon (son of Nigoğos, born 1855) listing his guardian as 'M. Donon', a relative of poet, writer and critic Théophile Gautier (1811-1872), illustrates that the Balyans made use of these links, at least on a social level. ${ }^{38}$ 
The head of the Sainte-Barbe was Alexandre Labrouste (1796-1866). His brother Henri was part of the Romantic movement that distanced itself from the traditional methods of the Beaux-Arts and espoused that architecture should not copy ideal models but reflect society. ${ }^{39}$ These architects, as Van Zanten has written, 'understood polychromy as a clothing of a structural skeleton with objects, inscriptions, and scenes communicating the building's social function and history'. ${ }^{40}$

Armenian sources suggest that Nigoğos Balyan had a special connection with the Labroustes. Krikor Odian (1834-1887), a close friend of Nigoğos who wrote his obituary in the newspaper $M e \breve{g} u$, states that Nigoğos was best-loved student of 'Baron Labrouste, Headmaster of the School'. ${ }^{41}$ The newspaper Masis describes how Nigoğos learnt architecture in the classes of 'Baron Labrouste, director of the "Imperial School of Fine Arts". ${ }^{42}$

Through the social environment of the Sainte-Barbe, Nigoğos Balyan imbibed the romanticism that Labrouste championed. Odian states:

As a follower of the architectural school of revival/renaissance, he [Nigoğos] fortunately got rid of artificial rules and superstitions. He brought a very clear horizon where his beautiful imagination could fly freely. ${ }^{43}$

Odian adds that: 'This was a freedom, which was based on Rationalism that was introduced into the philosophy of Descartes and, in literature, by Victor Hugo, and which he encouraged to be introduced into our literature. ${ }^{, 44}$

Romantics promoted an understanding of the genius as a man endowed with 'semidivine forces of creation, thaumaturgical in his miraculous yield'. ${ }^{45}$ Ledoux portrayed the architect as an inspired genius who 'on his imaginary journey, entered a trance-like state'. ${ }^{46}$ Odian emphasized Nigoğos' 'imagination set free', his works' immortality and their being 'condemned to obscurity'.

Antoine-Laurent-Thomas Vaudoyer (1756-1846) explained how architecture expressed sensations inspired by nature through imitation. ${ }^{47}$ Odian evoked how Nigoğos crafted his architecture on the banks of the Bosphorus in collaboration 'with the beauties of nature' and shaped them through his intelligence, talent for artistic beauty and fecund imagination. ${ }^{48}$

Nigoğos' participation in romantic tropes is underlined by Gautier's description of the Dolmabahçe Palace. ${ }^{49}$ Gautier described its ornament as 'not Greek, nor Roman, nor Gothic, nor Saracen, nor Arab, not yet Turkish' and likened it to the masterpieces of Venice,

Plateresco and cathedrals. Foreshadowing Ruskin's obsession with the blue of the lagoon and the white of the Doge's Palace, Gautier referred to the contrast between the marble of Dolmabahçe and the azure of the sea. In an echo of Odian, Gautier added that Dolmabahçe was 'built for immortality'. 50

Nigoğos learnt Parisian techniques for architectural communication through the SainteBarbe's cours de dessin. It is also likely that he attended the atelier of Henri Labrouste. In these settings, Nigoğos would have been exposed to the methods of the romantic rationalists (using inscriptions and scenes to communicate a building's function and meaning). Nigoğos' adaptation of this to Ottoman traditions can be seen in Dolmabahçe Palace. 
Dolmabahçe Palace [Figure 1] was completed in 1856 during the reign of Abdülmecid. This period saw the Tanzimat reforms, which modernized Ottoman institutions and subjecthood along egalitarian lines. ${ }^{52}$ The move from the Topkap1 Palace to the Bosphorus allied Abdülmecid with the consulates, social and commercial life of Pera. Abdülmecid's palace was also built to coincide with Ottoman entry into the Concert of Europe. Dolmabahçe was thus crafted to communicate resurgent Ottoman identity.

$<$ Figure One >

Armenian sources state that although Karapet Balyan was architect of the Dolmabahçe, Nigoğos was responsible for some features, namely, the Treasury Gate and Audience Hall. ${ }^{53}$ These parts are characterized by expressive ornament, showing the input of the linguistic culture of the Sainte-Barbe.

The Treasury Gate [Figure 2] was the ceremonial entrance to Dolmabahçe. Its fusion of modes of architectural communication taught in Paris (the model of the triumphal arch) with an Ottoman message of sovereignty set the tone for the rest of the palace. Although entrance portals were a feature of Ottoman mosques and the Topkap 1 Palace, where they were topped by an inscription and sultan's monogram (tuğra), the Treasury Gate at Dolmabahçe took the shape of a triumphal arch. This choice invoked the Ottomans as heirs to the Romans, but also Napoleon's Arc de Triomphe (1806-36) and Arc du Carrousel (1806-08).

$<$ Figure Two $>$

Ottoman architecture communicated according to a competitive discourse with other traditions. ${ }^{54}$ Kritovoulos of Imbros' description of Mehmed II's building works sheds light on this mentality: 'For he was constructing great edifices which were to be worth seeing and should in every respect vie with the greatest and the best of the past. ${ }^{55}$ In the use of a triumphal arch, the Treasury Gate heralded the Ottomans as foremost empire of the nineteenth century.

On a pragmatic level, the triumphal arch was a reflection of Parisian educational practice. Jacques-François Blondel (1705-1774)'s textbook instructed architects on techniques for evoking the sovereignty of the ruler, including triumphal gates. ${ }^{56}$ Despite this assimilation of Parisian architectural communication, details of the Treasury Gate were adapted to express its local relevance. First, the arch was crowned by an inscription and tuğra, following Ottoman traditions. Second, the carved decoration amplified this message of Ottoman power.

The carved ornament in the Dolmabahçe was a departure from Ottoman traditions, which had been governed by a system of decorum, wherein ornament highlighted elements of the structure. Although in the eighteenth century relief carving became more widespread, the ornamental overlay seen at Dolmabahçe shows the input of the linguistic culture of the romantics. As Gautier noted, Dolmabahçe [Figure 3] 'makes the façade of a building resemble a gigantic piece of goldsmith's work'; '[i]t is a palace, which might be the work of an ornamentist. ${ }^{57}$ Carved ornament was a romantic preoccupation: in La Comédie de la mort, Gautier depicted architecture that was composed of feston and dentelle and he engaged in 
'embroidering his construction' to the extent that 'he calls the very notion of function into question' through his purposely self-indulgent form. ${ }^{58}$

$<$ Figure Three>

The ornamental overlay of Dolmabahçe communicated a distinctly Ottoman message. The motifs depicted - Corinthian capitals, neo-classical friezes, baroque urns, shells, S-scrolls, brooches, cross hatching and neo-renaissance garlands-were symbols of power (dynastic brooches), or evoked plenty (fruit, flowers, shells, urns). American traveller Harriet Trowbridge Allen (1841-1877) noted: 'The whole of Europe had been laid under tribute to complete this Oriental palace. ${ }^{59}$ The inscription of the gate [Figure 4] proclaimed that the abode had become one of imperial pomp (makam şevket oldu) thanks to Abdülmecid.

$<$ Figure Four $>$

$<$ Figure Five>

The effect of these symbols was furthered by the presence of the tugr ra. When he visited Dolmabahçe, Louis Bunel, who wrote an account of his pilgrimage to the Holy Land, remarked: 'In the middle of the columns, the bas-reliefs, rosettes, and badges, appears surrounded by all the wealth and prestige of this art the cipher of the sultan, on its gold on green background. ${ }^{60}$ The tuğra was repeated around the palace: on mirrors, on frames and in the painted ceiling in the hamam room [Figure 5]. On the exterior, the tugra crowned every triumphal arch [Figure 6] and each facade [Figure 7]. The Parisian vocabulary (of symbols of plenty and power) proclaimed the message of Ottoman supremacy.

$<$ Figure Six $>$

$<$ Figure Seven>

The Audience Hall of the Dolmabahçe Palace [Figure 8] was the site for ceremonial and balls covered by L'Illustration and Le Monde Illustré. It was a huge interior space crowned by a dome, hidden by a gable so that it would not break the rules of decorum (adab) governing Ottoman architecture and impose on mosques. Its painted decoration mirrored that of the Treasury Gate.

$<$ Figure Eight $>$

This echoing of ornament around the palace created a playful and sensory effect and was another aspect of the linguistic culture of the romantics. Motifs were repeated in different techniques (stone carving, painted and gilded stucco), thus drawing attention to their artifice. Dolmabahçe is reminiscent of the Opéra of Garnier, his 'intuitive creative mode' and 'architectural empathy': most notably the changing functions of the rooms as spectators moved around. ${ }^{61}$ There is a similar play between the motifs and techniques in ceremonial rooms, and the use of decorative showpieces such as the crystal staircase through which 
visitors entered the palace [Figure 9]. Dolmabahçe, like Opéra, provoked a reaction between the human senses and their environment. ${ }^{62}$ However, at Dolmabahçe, this communicated Ottoman messages.

$<$ Figure Nine>

Elements of the decorative vocabulary had distinct symbolic meanings. This was a reflection of the iconoclasm of Ottoman art: thus, in place of portraits of the ruler there was his tugrra, a scroll represented reforms, a trumpet reflected Westernizing culture, and Constantinople's vistas showed territorial sovereignty.

Although floral bouquets were seen in the eighteenth century, at Dolmabahçe they were depicted in a theatrical composition, with frames and curtains. The bouquet of roses was incorporated into the Ottoman coat of arms because it signalled to the magnanimity of the state. ${ }^{63}$ Reflecting this heraldic role is the positioning of a bouquet at the apex of the crystal staircase, where it is depicted alongside militaristic symbols [Figure 10].

$<$ Figure Ten>

The trompe l'oeil dome of the Audience Hall similarly relied on symbols to communicate its message. In the pendentives, floral bouquets in urns, placed within golden frames and dramatic curtains, held an emblematic role [Figure 11]. In the cupola, triumphal arches formed a frieze as a reference to the mihrab of a mosque wherein arches pointed toward the qibla. In the Ortaköy Mosque [Figure 12], also built by Nigoğos, rows of mihrabs were painted in the dome, echoing that in the prayer hall. In the Dolmabahçe Palace, these arches contained a cartouche that was a reminder of the tuğra, alluding to the sovereign power of the sultan.

<Figure Eleven>

$<$ Figure Twelve>

The Dolmabahçe shows how Nigoğos had assimilated the methods of romantic rationalists. He used an ornamental overlay (in stone carving and paintwork), including symbols and inscriptions, to express the function and meaning of the palace. However, although the vocabulary came chiefly from Europe (renaissance, baroque, neo-classicism), it was adapted to communicate an Ottoman message.

The linguistic culture (or mode of architectural communication) of the romantics was tailored to a specifically Ottoman form at Dolmabahçe. The structure did not depart from plan types of Ottoman houses: its regularized facade housed a sofa (side spaces or eyvans jutting out from a central hall). ${ }^{64}$ The traditional house, including the sofa, became a focus of Turkish architectural historians in the early republic. ${ }^{65}$ The sofa was even charted back to tents in early Turkic societies. ${ }^{66}$ 
The sofa was consistently used in imperial palaces and pavilions, as Sedad Hakkı Eldem's studies have shown. ${ }^{68}$ It is clear from his plan of Dolmabahçe that the palace consisted of consecutive sofas, connected by corridors. ${ }^{69}$ This irregular plan was concealed by masonry walls that gave the palace the exterior appearance of Neo-Classicism.

The adherence to the sofa plan underlines that Nigoğos' practical approach was not fundamentally altered by his experience at the Sainte-Barbe: he continued to draw on local planning types. This was given a new surface language in the form of a Neo-Classical facade, adorned with ornament that spoke its meaning. The tropes of romanticism were evoked through this expressive ornament. However, the imaginative power of Nigoğos' composition was manipulated to convey the plenty of the empire under Abdülmecid. This was interactional expertise utilized in the service of the sultan.

\section{The Language of the École Centrale: The Technical Education of Serkis Balyan}

The Balyans' exposure to a Parisian technical education began at Sainte-Barbe. The school catered to students heading for the grande écoles and the 1845 prospectus boasted of 'the force of the scientific education', led by Labrouste and Marie Parfait Alphonse Blanchet (1813-1894). ${ }^{70}$ Courses included geometry, descriptive geometry, arithmetic, algebra and trigonometry. ${ }^{71}$

Developed by Gaspard Monge (1746-1818) and promoted through the curriculum at the Polytechnique, descriptive geometry represented three-dimensional objects in two dimensions. It was used to solve spatial problems in the design process, breaking them down into parts, and allowing for the generation of complex forms. When he moved on to attend the École Centrale in 1850, Serkis Balyan received a more thorough training in these technical skills.

The École Centrale was established in 1829 to encourage industrialization. ${ }^{72}$ Whereas the Polytechnique fed the military, the Centrale focussed on the practical application of the sciences and teaching of general subjects to explain the logic behind the theories. In the second year, students moved on from general subjects to a specialization in mechanics, construction, metallurgy, or chemistry.

Armenian sources state that Serkis Balyan attended the Centrale. ${ }^{73}$ Within the private archives of the school, student registers for 1850 and 1851 do list Serkis. However, unlike the other students, he had no specialty indicated. Instead, negative comments on his attendance and participation are noted and a letter from his guardian states that Serkis 'made the decision to quit the school'. Serkis only attended two months in his second year, according to the register.

Despite this lack of commitment, Serkis learnt scientific procedures at the Centrale during his first year that aided his subsequent works. In addition to mathematical skills like descriptive geometry, geometrical analysis and mechanics, he attended courses in architectural and topographical drawing, metallurgy, machines of line, raising buildings, raising machines, industrial design, industrial physics and transmission of movement. Moreover, a broader influence of Centrale pedagogy must have been the pragmatic approach of Louis-Charles Mary (1791-1870). 
Mary was professor of architecture and public works from 1833 until 1864. Student notebooks from Mary's architecture course show that its practical basis involved a logical progression from the analysis of 'elements of edifices' to 'examination of diverse edifices' (halls, markets, shops, etc.). Mary focused on problem-solving and skills: his course on public works included instructions (tools, calculations, procedures) on how to construct roads, bridges, water flows, and artificial navigation. ${ }^{74}$

Serkis' proposal for an Ottoman school for arts and industry, written in $1881,{ }^{75}$ shows some impact of Centralien pedagogy. It espoused the same general education in the sciences followed by specialization. However, it also included lessons on classical and non-Western architecture and on antiquities that Serkis learnt from the Beaux-Arts, as well as skills from the building sites of his father. The language of Ottoman patriotism used in the proposal expressed how Serkis intended 'to benefit the peoples of varied regions by nurturing and equipping individuals with knowledge and training for the future'. ${ }^{76}$ Serkis presented a collage of experiences, which he hoped would aid the empire's future.

Serkis' Ottoman Company for Public Works, established in 1873, also shows some impact of the Centrale's practical approach. This company engaged in activities resembling Mary's course. However, these engagements were, again, presented through the language of Ottomanism (promoting Ottoman power, resources and self-sufficiency): for instance, it is stated that the company was founded to supply building projects because '[e]very country had its own factories, and because the Empire had to make continuous demands to Europe (for goods), it made losses. ${ }^{77}$

Serkis' application of a pragmatic architectural language is shown in his 'building types'. At the Centrale, these were taught through the study of well-known examples. Student notebooks show, when teaching market halls, the plan, elevation and dome of the Halle aux blés de Paris (grain exchange) was drawn in one class and Les Halles centrales was dealt with in the next. Among these types were residential buildings, such as 5 rue de la Paix [Figure 13]. ${ }^{78}$ At the Beaux-Arts, types had an ornamental emphasis. ${ }^{79}$

$<$ Figure Thirteen>

Akaretler (terrace or row houses [Figure 14]), built in the early 1870s, shows Serkis' adjustment of a Parisian residential building to the Ottoman setting. Terrace houses were associated with simplicity and nobility in architecture, such as Place Royale (now Vosges) built in $1612 .^{80}$ Akaretler took this model, as elegant residences for the sultan's court. Their uniform facade and rectangular plan stood in contrast with Constantinopolitan buildings that continued to be wooden and used the sofa plan. ${ }^{81}$

$<$ Figure Fourteen>

Akaretler, constructed on a steep slope, as a route leading to the Aziziye Mosque of Abdülaziz, required technical skills perhaps akin to Mary's instructions on levelling land [Figure 15]. ${ }^{82}$

\section{$<$ Figure Fifteen>}

The design integrated Parisian approaches to urbanism: the terraces forming an entire quarter were reminiscent of the space around Garnier's Opéra where 'axial streets and nodal squares 
converge in one continuously unfolding scenographic experience... ${ }^{, 83}$ However, Akaretler was on a much smaller scale than the complex arteries of Paris, and its function, to form the passage of the sultan from palace to mosque for Friday prayers (selamlık), was a peculiarly Ottoman one..

The ambiguity of Serkis' assimilation and adaptation of the language of the Centrale reflects his enrollment status as well as his continued attachment to his Ottoman identity. Serkis' works, such as his 1881 proposal and Akaretler, demonstrate how he combined elements from the Centralien, as well as the Beaux-Arts approach. He, like Nigoğos, put these to use alongside local traditions of display and meaning. . Serkis appropriated the methodology of the Centrale in order to build Akaretler; he implemented a Parisian notion of elite residences and choreographing the city. However, these aspects of Parisian linguistic culture communicated his Ottomanism.

\section{The Language of the Beaux-Arts: Revivalist Ornament}

Armenian sources assert that Serkis attended the Beaux-Arts. ${ }^{84}$ On October 24, 1848, Serkis applied to the school as a foreign student, ${ }^{85}$ but he did not attend until later. In an 1860 register for Architectes Aspirants, ${ }^{86}$ a 'Palean' is listed as a student of Juls Rebout. ${ }^{87}$ There is a record of 'Palean' again on August 31, 1864, as a student of Louis-Jules André (18191890), in Construction Générale. ${ }^{88}$ These dates match Serkis' second stay in Paris between 1860 and 1864.

A focus of Beaux-Arts pedagogy was architectural composition. Courses would be assessed by concours, or competitions, for which the tutor would propose a type of building and each student would produce a project fulfilling the requirements (for 'construction in wood', a market hall for the sale of grain was proposed on April 4, 1864 [Figure 16]). ${ }^{89}$ In the ateliers, students would improve their skills in drawing and composition. ${ }^{90}$ As Blondel indicated, these competitions developed the passion and courage of the students so that they would come up with winning drawings. ${ }^{91}$ This implies that students' architectural communication was encouraged to foster the kind of designs that would gather the attention of judges.

\section{$<$ Figure Sixteen>}

Style was of central importance to the linguistic culture of the Beaux-Arts. Although the projects set by course tutors did not always include specifications about style - this is the case for a 'colonial museum' in 1910, for instance ${ }^{92}$ - many did offer a model to be followed, for instance, a 'palace in the style of the Barberini Palace' [Figure 17], for which a plan and façade were given. ${ }^{93}$ As Van Zanten states: 'choice as the first act of the design process manifests the eclectic position taken by the École at the end of the century', these choices or 'generative ideas', forming the 'battle of the styles' were then manipulated in order to achieve overall structural and decorative unity. ${ }^{94}$

\section{$<$ Figure Seventeen>}

By the late nineteenth century, the 'battle of styles' could encompass a wide range of models, as is shown in a text written by Professor of decorative arts, Pierre-Henri Mayeux (18451929). ${ }^{95}$ Within the three 'modes' of decoration were many possible choices including 'Louis XIII', 'Régence' and 'Byzantin'. ${ }^{96}$ Ornament 'from nature' could be Egyptian, Persian, Japanese or Gothic, ${ }^{97}$ whereas 'geometric' art chiefly came from Arab and Moorish styles. ${ }^{98}$ 
Serkis Balyan's project drawings [Figure 18] showing the interior of the Çırağan Palace of Abdülaziz (completed 1871), expose his Beaux-Arts training. Serkis developed drawing technique in the ateliers, hoping to attract the attention of his patrons. ${ }^{99}$ His sketches contrast with the two-dimensional traditions for architectural drawing in the Ottoman Empire. In his designs, Serkis delineated every aspect, from the bright colours and intricate design of the wall tiles [Figure 19], to the carved marble banisters, to the Gothic windows in the dome. $\mathrm{He}$ even signed the sketches, showing his vision of himself as an architect in the European sense.

$<$ Figure Eighteen>

$<$ Figure Nineteen $>$

Serkis' approach to planning also followed the Beaux-Arts modes of communication. His plan for the Çırağan Palace, as drawn by Mimar Sedad (1908-1988), follows a version of the sofa. ${ }^{100}$ However, in contrast with the plan of Dolmabahçe, the Çırağan is a single sofa that is symmetrical and simplified. This axial and modular focus was a key element of the BeauxArts training: ${ }^{101}$ Serkis had adapted this to an Ottoman plan type.

Serkis' Çırağan Palace drawings show how he assimilated the Beaux-Arts 'battle of styles'. An exotic coating of Islamic ornament (arabesque patterns, multi-foil arches, muqarnas, interlocking-stars, blind niches in primary colours and gilding) was combined with attentiongrabbing showpieces such as an internal fountain [Figure 20]. Ottoman features such as cartouches of the wall decoration, panels imitating Ottoman mirror kufic and turquoise hexagonal tiles making reference to the (early Ottoman) Green Mosque and Mausoleum of Bursa were combined with Gothic fenestration.

$<$ Figure Twenty >

Çrrağan's incorporation numerous historical styles reflected the teaching of the Beaux-Arts. In 1864, the same year that Serkis Balyan attended classes, Viollet-le-Duc taught aesthetics and the history of art (esthétique et histoire de l'Art). ${ }^{102}$ Eugène Emmanuel Viollet-le-Duc (1814-1879) emphasized that students should learn about theory, archaeological discoveries and what different traditions had in common. ${ }^{103}$

An outline of the class given by Lucien Magne (1849-1916), his successor, sheds light on pedagogy. ${ }^{104}$ Magne dealt with the art of other cultures summarily: in a course concentrating on antiquity, Greece and Rome, there was a section on 'modern architecture', which stretched from Latin, Byzantine, Gothic, Renaissance, monastic and Arab architecture, to China, Mexico and Peru. Arab architecture was defined simplistically as: 'byzantine [in] origin, modified by the oriental imagination, characterized by the use of the trefoil arch'. ${ }^{105}$ Exotic building types were focused on, for example 'palaces of Cairo', the Alhambra, medreses of Isfahan and 'mosques surmounted with onion domes'. Encapsulating the generalizing conception of Islamic art is the comment that 'all of the countries of the Orient which have adopted the religion of Muhammad possess monuments of Arab architecture: Turkey, Persia, India etc. ${ }^{106}$

Despite his orientalizing comments, Magne's approach had an analytical basis. Students produced plans, elevations and drawings of historical monuments, such as the cloister of the 
hospital of Saint-Jean d'Angers [Figure 21]. ${ }^{107}$ That similar methodology lay behind the design of the Çırağan Palace is suggested by a reference to Serkis' brother Agop sending artists to Spain and North Africa. ${ }^{108}$

$<$ Figure Twenty One>

The meaning of the Islamic and Gothic elements seen in Çırağan Palace is indicated by a text by Viollet-le-Duc. In his introduction to L'Architecture et Decorations Turques (1874), written by his disciple Léon Parvillée, Viollet-le-Duc stressed how the Turks had adopted the art forms of those they had conquered as well as those of their religion and that it was difficult to identify anything 'local' within this mixture of Persian, Arab and 'Hindu'. ${ }^{109}$ Viollet-le-Duc also identified relationships to European medieval and Crusader works. ${ }^{110}$

$<$ Figure Twenty Two $>$

The Valide Mosque (1872) built by Serkis for the mother of Sultan Abdülaziz in Aksaray, shows a related vision of the confluence of architectural traditions. The exterior [Figure 22], covered with relief carving, displays various Islamic repertoires: Mughal onion domes, Seljukid pyramidal vaults as well as Ottoman cartouches. The interior [Figure 23], decorated with bright paintwork, referenced Ottoman Bursa: blind niches, cartouches, and muqarnas friezes, along with the Mughal onion dome of the minbar, as well as the classic Ottoman mihrab. As in the Çırağan Palace, Islamic inferences were combined with Gothic fenestration. As in the Dolmabahçe Palace and Ortaköy Mosque, a trompe l'oeil dome dominated the interior [Figure 24].

$<$ Figure Twenty Three>

$<$ Figure Twenty Four $>$

This dome in particular elucidates the nature of the revivalism in the Valide Mosque. Within the illusionistic decoration, Islamic motifs such as muqarnas, multi-foil arches with ablaq, can be seen alongside more specific allusions, such as arabesques in the style of Ottoman Bursa and the central calligraphic medallion in classical Ottoman sülüs script. The bouquet of flowers in an urn, symbol for the magnanimity of the state, unifies these elements.

The categorization of the Valide Mosque and Çırağan Palace in the Usul-u Mimari-i Osmani (1873) as an 'Ottoman Renaissance' in fact explains the intention behind the syncretic nature of their decoration. Merging Ottoman and Islamic styles with Gothic fenestration, they displayed their (perceived) roots, according to theories such as those of Magne and Viollet-leDuc on the interrelation of historic styles. This vision of the genealogy of Ottoman architecture was joined by bright colours and trompe l'oeil in order to evoke rebirth.

The syncretic revivalism mixed seemingly contradictory styles (Gothic, Moorish, Ottoman...) in one building in order to make a cohesive whole. It can be likened to the romantic eclecticism of the Marseilles Cathedral (1845-1893) by Léon Vaudoyer, which blended Byzantine, Islamic and European styles to communicate the role of the city as an intersection of cultures. Serkis Balyan's related invocation of historical styles was not a 
reflection of the interaction of European and Islamic influences, but was deliberately constructed to convey meaning.

The architectural works of Viollet-le-Duc were historicist in nature and geared toward the recreation of a particular historic monument to communicate national purity. Viollet-le-Duc disdained the pluralism that was encouraged by the Beaux-Arts, its superficial adopting of formsand 'grotesque medley of styles'.' 111

The choice of a syncretic approach can perhaps be attributed to the influence of André, who was one of Serkis' patrons in the ateliers. ${ }^{112}$ André's works, such as the Museum of Natural History, followed Labrouste's lead in combining modern techniques with classical inspiration and epigraphic content communicating function and meaning. However, Ottoman architecture itself had, as Viollet-le-Duc pointed out, assumed a variety of traditions (being 'above all' a branch of Persian and Arab art). ${ }^{113}$

Although the 'Ottoman Renaissance' was an articulation of views that were circulating at the Beaux-Arts, crafted into a syncretic design-whole, it was not orientalist architecture. Instead, it was part of a spate of activities promoting Ottoman traditions in the 1860s and 70s. Ottomans joined the international expositions to increase international prestige and trade, by demonstrating the value of their handicrafts. These stressed Ottoman-Islamic heritage and identity: Salaheddin Bey, head of the delegation to the 1867 exposition, likened Abdülaziz's visit to Harun al-Rashid sending presents to the 'greatest monarch of the Occident'. ${ }^{114}$

Parvillée, who had worked on the Dolmabahçe Palace, conducted fieldwork in Bursa, aiming to distance oriental style from 'une question de mode'. Instead of applying a certain number of motifs and borders to create 'un ensemble harmonieux', he intended for his studies to identify 'the line, invisible but real, which comprises the taste, which can be called the art, of the civilization'. ${ }^{115}$

The decorator Sopon Bezirdjian (1841-1915) gives further evidence of this desire to use Beaux-Arts methodologies to rehabilitate the position of oriental art. Bezirdjian published an album of designs in London in 1889, wherein he noted the passion of Abdülaziz for palaces 'in true oriental style' and his love for Turkish, Persian and Arabian styles. Bezirdjian stressed the need for academic study to correct how 'Oriental peoples are improperly represented to Western nations'. ${ }^{116}$ Bezirdjian's drawings show how he studied Oriental art forms, making sketches of recognizable Ottoman patterns [Figure 25], Far Eastern ones and Armenian historic architecture. ${ }^{117}$ Bezirdjian's close working relationship with Serkis (he collaborated on nearly all of his works) suggests that his reference to palaces in 'true oriental style' can be seen as an accurate expression of Serkis' intent.

$<$ Figure Twenty Five $>$

It is clear that Serkis Balyan took on aspects of the intellectual world and practical methods of the Beaux-Arts. These were circulated within his working milieu, including Parvillée and Bezirdjian, as well as the team responsible for the Usul, some of whom worked on his constructions. ${ }^{118}$ Serkis expressed prevailing ideas on the genealogy of Ottoman architecture through syncretic revivalism in the Valide Mosque and Çırağan Palace, using an ornamental overlay to communicate a message of Ottoman resurgence.

\section{Conclusion: Parisian expertise adapted to an Ottoman core.}


At the Sainte-Barbe, the Centrale and the Beaux-Arts, Nigoğos and Serkis were exposed to the linguistic culture of Parisian architecture and new methods of architectural communication. They assimilated these and adapted some of their aspects to the Ottoman setting.

At the Sainte-Barbe, Nigoğos came into contact with romanticism, assimilated its tropes and formulated his own version of its architecture in the Dolmabahçe Palace. Nigoğos used external and internal ornament to express the function and meaning of the building, following practitioners such as Henri Labrouste. This ornament was employed in a highly original way, presaging the emotive architecture of Charles Garnier. However, Nigoğos used Parisian decoration and its vocabulary to express Ottoman sovereignty: through inscriptions, symbolic motifs and the display of the tugrra, as well as through the design of the palace, taking into account the competitive discourse of Ottoman architecture. Nigoğos made sure that Dolmabahçe remained rooted to the sofa of Ottoman residential architecture. Therefore, although its surface communication adapted the language of Parisian romanticism, its core did not depart from local traditions.

Serkis Balyan followed a similar approach. Although he attended the Sainte-Barbe, the Centrale and the Beaux-Arts, Serkis used his new expertise alongside commitment to the traditions, practices and identities of the empire. He built the earliest Ottoman terraced buildings, following models offered at the Centrale and the Beaux-Arts. However, Akaretler were not sold on the open market, but were reserved for the sultan's court and formed the sultan's route to Friday prayers. Parisian architectural modes were exploited to reinforce the structures of the empire.

Serkis assimilated the Beaux-Arts approach to architectural communication and focused on the importance of composition and style. Following his exposure to the system of competitions, Serkis' drawings integrated formal and technical features engineered to catch attention. Notions about the history of Islamic architecture taught by Viollet-le-Duc and Magne were incorporated into the Valide Mosque and the Çirağan Palace, but, like Nigoğos, Serkis continued to use Ottoman floor plans.

. On a pragmatic level, Nigoğos and Serkis learnt technical skills that helped their building works develop on a larger scale and which enabled Serkis to found his public works company. On a formal level, they gained an expertise that enabled them to use architecture to communicate in a different way. And yet, Nigoğos and Serkis continued to express Ottoman messages through their adaptation of Parisian linguistic culture and continued to build according to Ottoman structural types. This embodied the architectural form of interactional expertise, used in the service of the sultan. 
${ }^{1}$ Rahip Yeprem Boğosyan, Balyan Kertasdanı (Vienna: Mekhitaryan Tparan, 1981), 133 on Nigoğos, 178 on Serkis, 245 on Agop.

2 Pars Tuğlacı, The Role of the Balian Family in Ottoman Architecture (Istanbul: Yeni Çığır, 1990), 303.

${ }^{3}$ Kevork Pamukciyan, Biografileriyle Ermeniler (Istanbul: Aras, 2003), 97-100.

4 Aygül Ağır, 'Balyanlar'ın Eğitimleri Üzerine Notlar', in Afife Batur'a Armağan. Mimarlık ve Sanat Tarihi Yazıları, ed. Aygül Ağır, Deniz Mazlum and Gül Cephanecigil (Istanbul: Literatür, 2005), 65-71.

${ }^{5}$ My book (Architects of Constantinople: The Balyan Family and the History of Ottoman Architecture (London and NY: IB Tauris, 2015)), includes a chapter on the Balyans' education. This article adds details on the educational experience and how this was adapted. ${ }^{6}$ Celal Esad Arseven, Türk San'atı (Istanbul: Akşam Matbaası, 1928), 171.

${ }^{7}$ Arseven, Türk San'atı, 172.

${ }^{8}$ Sibel Bozdoğan, 'Reading Ottoman Architecture Through Modernist Lenses: Nationalist Historiography And The "New Architecture" In The Early Republic', Muqarnas, vol. 24 (2007): 201.

${ }^{9}$ Bozdoğan, 'Reading Ottoman Architecture', 202.

12 'Ottoman Renaissance' is given as 'usul-i mimari-i 'Osmanının mebde-i ihyast' (reviving the source of Ottoman architecture). Ahmet Ersoy, "On the Sources of the 'Ottoman

Renaissance': Architectural Revival and its Discourse During the Abdülaziz Era (1861-76)" (Unpublished PhD Thesis, Harvard, 2000), 269

${ }^{13}$ Ahmet Ersoy, 'Architeture and the Search for Ottoman Origins In The Tanzimat Period', Muqarnas, vol. 24 (2007): 133.

${ }^{14}$ Ersoy, On the Sources of the "Ottoman Renaissance", $311 \mathrm{n} 6$.

${ }^{15}$ Ahmet Ersoy, 'Sarkis Bey's Dream: An Alternative House of Sciences and The Fall of the Traditional Builder' in Armenian Architects of Istanbul in the Era of Westernization, ed.

Hasan Kuruyazıcı (Istanbul: International Hrant Dink Foundation Publications, 2010), 58-79.

${ }^{16}$ Harold F. Schiffman, Linguistic culture and Language Policy (London and New York: Routledge, 1996), 5.

${ }^{17}$ Schiffman, Linguistic Culture and Language Policy, 7.

${ }^{18}$ Jean-Claude Bringuier, Jean Piaget, Conversations with Jean Piaget (Chicago: University of Chicago Press, 1980), 43.

${ }^{19}$ Ekmeleddin Ihsanoğlu, Science, Technology and Learning in the Ottoman Empire (Ashgate: Aldershot, 2004), 62.

${ }^{20}$ Harry Collins, 'Interactional Expertise as a Third Kind of Knowledge', Phenomenology and the Cognitive Sciences, 3, 125-143 (2004), abstract, 125.

${ }^{21}$ Collins, 'Interactional Expertise', 126.

${ }^{23}$ Collins, 'Interactional Expertise', 127.

${ }^{24}$ Harry Collins and Robert Evans, Rethinking Expertise (Chicago: University of Chicago Press, 2007), 59.

${ }^{25}$ Collins, 'Interactional Expertise', 135.

${ }^{26}$ Harry Collins, Robert Evans and Michael E. Gorman, 'Trading Zones and Interactional Expertise', in Trading Zones and Interactional Expertise: Creating New Kinds of Collaboration, ed. Michael E. Gorman (MIT Press, 2010), 15.

${ }^{27}$ Teotik, Teotik Amenun Daretsuytsi (1921), 256-67; Meğu, March 10, 1858, 5; Boğosyan, Balyan Kertasdanı, 178; Arşaluys Araradyan, 1850 issue 378; Boğosyan: Balyan Kertasdanı, 245; Masis 1866 issue 772.

${ }^{28}$ Archives de Paris, D.50Z article no. 385, 1846 to 1847 and 1851 to 1852. 
${ }^{29}$ There is a 'Bellion' listed in D.50Z/385, 1846-1847, which may be Nigoğos.

${ }^{30}$ Marc Le Coeur, 'An Architect of Silence', in Henri Labrouste: Structure Brought to Light, eds Barry Bergdoll et al (New York: The Museum of Modern Art, 2013), 44.

${ }^{31}$ Archives de Paris, D.50Z/107, 24 Dec 1862.

${ }^{32}$ Vartan Artinian, The Armenian Constitutional System in the Ottoman Empire, 1839-1863: A Study of its Historical Development (Istanbul: Isis Press, 1988), 62.

${ }^{34}$ Archives de Paris, D.50Z/385, 1848-49 ; David Harvie, Eiffel, the Genius who Reinvented Himself (Stroud, Gloucestershire: Sutton, 2006), 7.

${ }^{35}$ Robert Jarvis, 'Pierre Victor Galland', The Art Amateur, vol.18, no.5 (April 1888), 108.

${ }^{36}$ Charles Séchan, Souvenirs d'un homme de théâtre 1831-55 (Paris, Calmann-Levy),

Preface by Adolphe Badin.

${ }^{37}$ Archives de Paris, D.11J/130, 1850, register of teaching personnel.

${ }^{38}$ Ağır, 'Balyanlar'ın Eğitimleri Üzerine Notlar', 65-70.

${ }^{39}$ Neil Levine, 'The Book and the Building: Hugo's Theory of Architecture and Labrouste's

Bibliothèque Ste-Genevieve', in The Beaux-Arts and Nineteenth-Century French

Architecture, ed. Robin Middleton (London: Thames and Hudson, 1982), 139.

${ }^{40}$ David Van Zanten, 'Architectural Polychromy: Life in Architecture', in The Beaux-Arts and Nineteenth-Century French Architecture, ed. Robin Middleton (London: Thames and Hudson, 1982), 200.

${ }^{41}$ Meğu, March 101858.

${ }^{42}$ Boğosyan: Balyan Kertasdanı, 178; Masis, issue 319, 1858.

${ }^{43}$ Me ğu, March 10, 1858, 4.

${ }^{44}$ Meğu, March 10, 1858, 4.

${ }^{45}$ Robert A. Nisbet, 'Genius \& Milieu', Proceedings of the American Philosophical Society, vol. 126, no. 6, (Dec, 1982): 441.

${ }^{46}$ Alice T. Friedman, 'Academic Theory and A.-L.-T. Vaudoyer's Dissertation sur

l'architecture', The Art Bulletin, vol. LXVII, no.1, (March, 1985): 118.

${ }^{47}$ Friedman, 'Academic Theory', 116.

${ }^{48}$ Meğu, March 10, 1858, 6.

${ }^{49}$ Théophile Gautier, Constantinople of To-day (1854) by Théophile Gautier, translated by

Robert Howe Gould (London: David Bogue, 1856), 300-301.

${ }^{50}$ Gautier, Constantinople of To-day, 300-301.

${ }^{52}$ Roderic H. Davison, Reform in the Ottoman Empire 1856-1876 (New York: Gordian Press, 1973), 28.

${ }^{53}$ Me ğu, March 10, 1858, 3

${ }^{55}$ Gülru Necipoğlu, Architecture, Ceremonial and Power: The Topkapı Palace in the Fifteenth and Sixteenth Centuries (Cambridge, Mass: MIT Press, 1991), 8.

${ }^{56}$ David Van Zanten, Building Paris: Architectural Institutions and the Transformation of the French Capital 1830-1870 (Cambridge: Cambridge University Press, 1994), 105.

${ }^{57}$ Gautier, Constantinople of To-day, 299-306.

${ }^{58}$ David Graham Burnett, 'The Architecture of Meaning: Gautier and Romantic Architectural Visions', French Forum, vol. 7, no. 2 (May 1982): 109.

${ }^{59}$ Harriet Trowbridge Allen, Travels in Europe and the East During the Years 1858-59 and 1863-64 (New Haven: Tuttle, Morehouse A. Taylor, Printers, 1879), 106.

${ }^{60}$ Louis Bunel, Jérusalem, La Cote de Syrie et Constantinople en 1853 (Paris: Sangnier et Bray, 1854/Elibron Classics, 2005), 375.

${ }^{61}$ Christopher Curtis Mead, Charles Garnier's Paris Opéra: Architectural Empathy and the Renaissance of French Classicism (New York and Cambridge MA: MIT Press, 1991), 231. 
${ }^{62}$ Bruno Girveau, 'Une architecture «qui parle aux yeaux, aux oreilles, au cœur et au passions»' in Bruno Girveau, ed., Charles Garnier Un Architecte Pour Un Empire, (Paris: Les Editions Beaux-arts de Paris, 2010), 14.

${ }^{63}$ Selim Deringil, 'The Invention of Tradition as Public Image in the Late Ottoman Empire 1808-1908', Comparative Studies in Society and History, vol. 35 no.1, (1993), 7.

${ }^{64}$ Sedat Hakkı Eldem, Türk Evi Plan Tipleri (İstanbul Teknik Üniversitesi, Mimarlık Fakültesi, 1954).

${ }^{65}$ Bozdoğan 'Nationalist Historiography', 212-3.

${ }^{66}$ Önder Küçükerman, Türk Evi (Istanbul: Apa Ofset Basımevi, 1985), 25-7.

${ }^{68}$ Bozdoğan, 'Reading Ottoman Architecture', 213.

${ }^{69}$ Eldem, Türk Evi, II, 146.

${ }^{70}$ Archives de Paris, D.50Z/107, booklet dated 15 Nov 1845.

${ }^{71}$ Archives de Paris, D.50Z/107, booklet dated 15 Nov 1845.

${ }^{72}$ Pothier, Françoise, Histoire De L'École Centrale Des Arts Et Manufactures (Paris:

Delamotte Fils et Cie, Libraires-Editeurs, 1887), 7-8.

${ }^{73}$ Luys (1880 issue 52).

${ }^{74}$ The (unnumbered) student notebooks or 'cahiers spéciaux' are kept in the private archives of the Centrale.

${ }^{75}$ BBK, Y.A. RES, D:9, G:27, 1298.S.02/1881.

${ }^{76}$ BBK, YA.RES D:9, G:27, 1298.S.02/ 1881.

${ }^{77}$ BBK, A)MKT.MHM, D:451, G:3, 1290.M.28/1873.

${ }^{78}$ École Centrale Private Archives, $2^{\text {nd }}$ Year Student Notebook 1862-63.

79 Annie Jacques, 'Introduction', in Les Dessins D'Architecture De L'Ecole Des Beaux-Arts, ed. Annie Jacques and Riichi Miyaké (Paris: Arthaud, 1988), 8.

${ }^{80}$ Pierre Lavedan, L'urbanisme à l'époque moderne : XVIe-XVIIIe siècles (Genève: Droz, 1982), 117.

${ }^{82}$ École Centrale Private Archives, ${ }^{\text {nd }}$ Year Student Notebook 1862-63, Leçon II, 7 novembre: 'Nivellement'..

${ }^{83}$ Chrisopher Mead, 'Urban Contingency and the Problem of Representation in Second Empire Paris', Journal of the Society of Architectural Historians, Vol. 54, No. 2 (Jun., 1995): 138.

${ }^{84}$ Teotik Amenun Daretsuytsi (1921), 263; Dzarig 1899, issue 56.

${ }^{86}$ Armenian spellings vary in Eastern or Western. The registers were signed by the students.

${ }^{87}$. Archives Nationales, AJ/52/38.

${ }^{88}$ Archives Nationales, AJ/52/161.

${ }^{89}$ Archives Nationales, AJ/52/133.

${ }^{90}$ Richard Chafee, 'The Teaching of Architecture at the École Des Beaux-Arts', in Arthur Drexler (ed), The Architecture of the Ecole des Beaux-Arts (Museum of Modern Art / distributed by MIT Press: 1977), 82.

91 Jacques, 'Introduction', 6.

92 Archives Nationales, AJ/52/ 132, Concours d'Emulation from 1910.

${ }^{93}$ Archives Nationales, AJ/52/133.

${ }^{94}$ David Van Zanten, 'Architectural Composition At The Ecole Des Beaux-Arts From Charles Percier to Charles Garnier', in Arthur Drexler, ed., The Architecture of the Ecole des Beaux-Arts (New York: The Museum of Modern Art / distributed by MIT Press, 1977), 115. ${ }^{95}$ Henri Mayeux, La Composition Décorative(Paris: Société Français D'Editions D'Art, 1885), 7-11. 
${ }^{96}$ Mayeux, La Composition Décorative, 42-48.

${ }^{97}$ Mayeux, La Composition Décorative, 48-61.

${ }^{98}$ Mayeux, La Composition Décorative, 64.

99 Jacques, 'Introduction', 6.

${ }^{100}$ Eldem, Türk Evi, II, 152.

${ }^{101}$ Van Zanten, 'Architectural Composition', 112 and 124 and 193.

${ }_{102}$ Archives Nationales, AJ/52/39.

${ }^{103}$ Eugène Viollet-le-Duc, Lectures on Architecture, trans. Benjamin Bucknall (London:

Sampson Low, Marston, Searle And Rivington Crown Buildings, 1877), 388.

${ }^{104}$ Archives Nationales, AJ/52/41.

${ }^{105}$ Archives Nationales, AJ/52/41.

${ }^{106}$ Archives Nationales, AJ/52/41.

${ }^{107}$ Archives Nationales, AJ 52/148.

108 Tuğlac1, The Role of the Balyan Family, 318.

${ }^{109}$ Léon Parvillée, L'Architecture et Decorations Turques (Paris: Ve A. Morel, 1874), preface by Viollet-le-Duc, ii.

${ }^{110}$ Ibid.

${ }^{111}$ Viollet-le-Duc, Lectures on Architecture, 447-9.

112 Archives Nationales, AJ/52/460 and AJ/52/35..

${ }^{113}$ Léon Parvillée, L'Architecture et Decorations Turques, preface by Viollet-le-Duc, ii.

${ }^{114}$ Salaheddin Bey, La Turquie à l'Exposition universelle de 1867 (Paris, 1867), frontispiece.

${ }^{115}$ Parvillée, L'Architecture et Decorations Turques, 2.

${ }^{116}$ Sopon Bezirdjian, Albert fine art album (London: John Heywood, 1889), 5.

${ }^{117}$ Bezirdjian's drawings are held by his family in London. They are in the process of being transferred into museum custody.

${ }^{118}$ Eugène Maillard worked on Akaretler and Aziziye Mosque. BBK, HR.TO, 464/57, 1878.9.8. Pietro Montani worked on the Valide Mosque and Çırağan Palace. Ersoy, On the Sources of the "Ottoman Renaissance", 98-99. 